\title{
Ponderosa Development: A Financial Reporting Case
}

Larry Watkins, Ph.D., CPA, Northern Arizona University, USA

Roxanne Stell, Ph.D., Northern Arizona University, USA

Brian Maris, Ph.D., CFA, Northern Arizona University, USA

\begin{abstract}
This case, or parts thereof, is appropriate for use in an undergraduate intermediate accounting course or an undergraduate/graduate financial accounting cases course. This case deals with various financial reporting issues such as interest capitalization, asset impairment, contingent items, and troubled-debt restructuring. This is all done with a backdrop of a bursting real estate bubble and a national credit crunch. The write-up of the solution to this case is also a useful vehicle for student preparation of either a professional memo or an executive summary. Both provide reinforcement of technical writing skills.
\end{abstract}

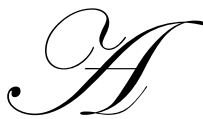

t the height of the real estate boom many development projects were envisioned and ultimately undertaken even though it was suspected that a real estate "bubble" had been created. In fact U.S. Federal Reserve Chairman Alan Greenspan said in mid-2005 that "at a minimum, there's a little 'froth' (in the U.S. housing market) ... it's hard not to see that there are a lot of local bubbles". ${ }^{1}$

Bubbles or not, Ponderosa Development Company (PDC) was formed in 2004 to create an elegant 68 condominium units and commercial/retail development near Flagstaff, Arizona known as Ponderosa Development (PV). PDC was originally a partnership consisting of Yaro Construction Corporation, John-Boy Capital Inc., and Peak Surgical Associates. Yaro Construction Corp. (Yaro) was the lead developer in the project and was experienced in large multi-use real estate projects. James Yaroslavski, the founder and major shareholder of Yaro, was an experienced craftsman that had morphed into a savvy contractor with an ability to develop beautiful projects of exceptional quality and do it within budget constraints. John-Boy Capital was founded by a local CPA, John Boynton, who had amassed a considerable fortune exploiting local commercial opportunities. John-Boy was the major financial backer of PV and was to provide management of PDC. Peak Surgical Associates (Peak), a professional corporation consisting of fourteen surgeons, had developed a reputation for shrewd business acumen by investing in a wide spectrum of ancillary medical ventures. PDC was their first foray into real estate development outside of the medical arena.

In 2005 the entities that made up PDC were in what seemed to be constant disagreement. Yaro had repeatedly failed to meet its commitments to PDC and while obviously well suited for management of the construction side of the project it appeared they were "over their head" when it came to appreciating the financial aspects of the project. After much consternation, in early 2006 John Boynton decided to exercise his pre-existing option to acquire all ownership interests in PDC. Although this meant borrowing what John considered a huge amount ( $\$ 10$ million) from Miners and Merchants Bank, he deemed it necessary to protect his investment. As part of this disaggregation of interests John-Boy acquired all interests in the residential real estate (condominiums) while Yaro and Peak retained the commercial/retail portion of the development.

During 2006 the condominiums of PV were essentially completed however, financial management problems had considerably lengthened the time estimated for completion of the commercial properties. Condominium pre-construction sales and sales during 2006 were significantly below projections. Total units sold at the end of 2006 were only seven. The disappointing sales numbers were attributed to a weak real estate market, tighter credit, and an oversupply of condominiums in the local market. Although very disappointed in the sales figures, John Boynton was confident that at December 31, 2006 the net realizable value of his development exceeded the capitalized cost. 
As economic conditions deteriorated further in 2007, sales of the residential units languished. Only five units were sold during the year and those sales required deep discounts. Additionally, the commercial portion of PV was still far from completion. John was reasonably certain the commercial properties would be completed and if successful that should stimulate condo sales. But when completion would happen was very uncertain. At December 31,2007 , the capitalized cost of the 56 remaining units was $\$ 11,200,000$. Most recent unit sales indicate that on average units have a market value of $\$ 194,000$. However, direct selling expenses for broker, title, and closing fees are approximately $5 \%$ of sales price.

To add insult to injury, John Boynton had to cope with the realization that there appeared to be some construction deficiencies in the condominium project. The use of a particular type of tubing for the radiant floor heating system had proven to be problematic in a number of units. It seems that one of the $\mathrm{HVAC}^{2}$ sub-contractors responsible for installation of the systems was inexperienced with the connecting process required for this particular product. The cost to repair the affected units was estimated at $\$ 1.2$ million. John-Boy has entered into arbitration with the general contractor to recover at least some of this amount, but as of the end of 2007 the repairs continue as does the arbitration process.

The sub-prime lending debacle and the related defaults had also created a series of economic problems for Miners and Merchants Bank (MMB), the lender that supplied the funding for PDC. After reviewing the situation the bank has declined to renew the loan agreement with PDC which is currently experiencing negative cash-flows from the PV project. MMB did not want to consider foreclose on the PV condominium project (especially since they have also loaned funds to Yaro and Peak for the commercial portion of the development) so they have agreed to settle the \$10 million debt with PDC for 85 cents on the dollar. John-Boy Capital provided the funds to pay the bank $\$ 8.5$ million with an unsecured loan from the founder John Boynton.

Grant Hire is the Chief Financial Officer for John-Boy Capital and now is responsible for the same functions at Ponderosa Development Company. Grant had been under considerable stress regarding the performance of PDC and PV and the corresponding cash flow issues. As the New Year approaches (January 1, 2008) his attention focuses on the reporting issues he will encounter with the December 31, 2007 financials. John Boynton has made it clear that he would like to capitalize as much interest related to PV as possible to lessen the damage economic conditions will no doubt inflict on the financials. There are other significant reporting issues Grant must address in regard to the upcoming reporting cycle as well.

Identify the significant financial reporting issues faced by Ponderosa Development Company and fully explain the accounting treatment that Grant Hire should utilize for each. 


\section{TEACHING NOTE, PONDEROSA DEVELOPMENT}

Intended Courses: This case, or parts thereof, is appropriate for use in an undergraduate intermediate accounting course or an undergraduate/graduate financial accounting cases course.

Topics Covered: This case deals with various financial reporting issues such as interest capitalization, asset impairment, contingent items, and troubled-debt restructuring. This is all done with a backdrop of a bursting real estate bubble and a national credit crunch.

The write-up of the solution to this case is also a useful vehicle for student preparation of either a professional memo or an executive summary. Both provide reinforcement of technical writing skills.

Case Questions: Although not included in the body of the case, to allow instructor discretion regarding guidance, the following questions can be provided to student users of this case. This provides somewhat more structure which may be appropriate for intermediate accounting students.

1. How much of the interest incurred in conjunction with the Ponderosa Development project can be capitalized for 2007 ?

2. How should Grant Hire treat the construction deficiencies for financial reporting purposes? What about the arbitration that is currently in progress?

3. How should Ponderosa Development Company (PDC) account for the $\$ 1.5$ million difference between the carrying value of the loan from Miners and Merchants Bank and the amount for which the debt was settled? Will the accounting treatment by the bank mirror PDC's?

4. Is it necessary for PDC to revalue its investment in Ponderosa Development for the December 31, 2007 financials?

5. If Grant Hire adopts International Financial Reporting Standards (IFRS) for financial statement presentation how would your answers to questions 1-4 differ?

\section{Case Solution (answers to questions):}

1. How much of the interest incurred in conjunction with the Ponderosa Development project can be capitalized for 2007 ?

Per SFAS No. 34 interest cost associated with inventories should be considered a period cost in general. However, interest costs related to assets produced as discrete projects (such as ships or real estate projects) for sale or lease should be capitalized. ${ }^{3}$ Because the project was substantially completed during 2006, the interest capitalization period would have ended at that point. Therefore no interest should be capitalized in $2007 .^{4}$

2. How should Grant Hire treat the construction deficiencies for financial reporting purposes? What about the arbitration that is currently in progress?

The construction deficiencies meet the definition of a contingent item. ${ }^{5}$ Since it appears that the probability of a loss relating to the asset is probable and the loss has been estimated to be $\$ 1.2$ million, a loss in that amount should be accrued. ${ }^{6}$ Additionally, a liability in that amount should be established (see item 4 below).

The arbitration process involving the general contractor gives rise to a gain contingency. ${ }^{7}$ While it is not appropriate to accrue a gain ${ }^{8}$ in this case it would be appropriate to disclose the ongoing arbitration in conjunction with the footnote discussion of the construction deficiency contingency. However, “... care shall be exercised to avoid misleading implications as to the likelihood of realization."

3. How should Ponderosa Development Company (PDC) account for the $\$ 1.5$ million difference between the carrying value of the loan from Miners and Merchants Bank and the amount for which the debt was settled? Will the accounting treatment by the bank mirror PDC's? 
The settlement of PDC's debt entails the granting, by the bank for economic reasons related to the debtor's financial difficulties, a concession that it would not ordinarily consider. ${ }^{10}$ Therefore this is considered a troubled debt restructuring.

Since PDC is satisfying its $\$ 10$ million MMB loan for $\$ 8.5$ million, they will recognize a $\$ 1.5$ million gain from troubled debt restructuring. ${ }^{11}$

Although not always the case, in this instance MMB's treatment will mirror PDC's. Most likely MMB had recognized the loan to PDC as impaired prior to the restructuring. In that situation MMB would reduce Allowance for Impaired Receivables for the $\$ 1.5$ million. If MMB had not previously recognized the loan as impaired it would be appropriate to charge Uncollectible Loan Expense for the $\$ 1.5$ million in conjunction with the write-off. ${ }^{12}$

\section{Is it necessary for PDC to revalue its investment in Ponderosa Development for the December 31, 2007 financials?}

At December 31, 2007 the carrying value of the project was $\$ 11,200,000$. Concurrently the remaining 56 units (68 total less 12 units sold) have an aggregate market value of $\$ 10,864,000$ (56 x $\$ 194,000)$. This appears to indicate that a decline in the utility of Ponderosa Development has occurred. This is not an impairment per se since impairments relate to property, plant, and equipment whereas in this case the real estate in question is actually inventory for PDC. The accounting literature indicates that a departure from the cost basis is required when the utility of inventory is no longer as great as cost. ${ }^{13}$ This is generally referred to as valuation of inventory at the lower of cost or market. The determination of market is the required next step in this process. Utility is usually indicated by the replacement cost of the goods in question by purchase or reproduction. However, replacement or reproduction prices are not appropriate as surrogates for utility when sales value minus cost of disposal is less ${ }^{14}$ as is the apparent case for the PV development.

PDC should write-down the carrying value of Ponderosa Development by $\$ 879,200$ and correspondingly recognize a loss on the write-down during 2007 . The write-down amount is determined as follows:

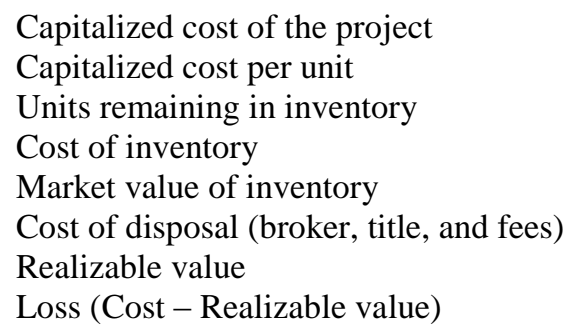

It is not necessary to reduce the market value of inventory by the anticipated cost to repair the HVAC deficiencies since that amount ( $\$ 1.2$ million) was recognized as a loss/liability in relation to the contingency (see response to question 2 above).

5. If Grant Hire adopts International Financial Reporting Standards (IFRS) for financial statement presentation how would your answers to questions 1-4 differ?

1. International Accounting Standard 23, Borrowing Costs provides for the capitalization of interest on inventories that take a substantial amount of time to complete. ${ }^{15}$ However, as with SFAS No. 34 , "[c]apitalisation of borrowing costs shall cease when substantially all the activities necessary to prepare the qualifying asset for its intended use or sale are complete". ${ }^{16}$ Therefore treatment under IFRS is the same as with U.S. GAAP.

2. With International Financial Reporting Standards there is a distinction between what is referred to as a provision and a contingent liability. A provision is a liability of uncertain timing or amount. ${ }^{17}$ 
Whereas a contingent liability is a possible obligation arising out of past events and that will be confirmed by the occurrence of non-occurrence of future event(s). ${ }^{18}$ In the situation PDC is experiencing, the uncertainty regarding the construction deficiencies would be treated as a provision since

\section{PDC has a}

"present obligation (legal or constructive) as a result of a past event; it is probable that an outflow of resources embodying economic benefits will be required to settle the obligation; and a reliable estimate can be made of the amount of the obligation." 19

In regard to the arbitration that is currently ongoing, based on IFRS this would be considered a contingent asset. However, contingent assets are not disclosed unless an inflow of economic benefits is probable ${ }^{20}$ which does not appear to be the case here.

3. IFRS regard what is known as a troubled debt restructuring in U.S. GAAP as "derecognition of a financial liability." To account for such transactions "the difference between the carrying amount of a financial liability (or part of a financial liability) extinguished or transferred to another party and the consideration paid, including any non-cash assets transferred or liabilities assumed, shall be recognised in profit or loss."21 Therefore PDC would recognize \$1.5 million in profit due to this derecognition (restructuring) transaction.

4. Under IFRS inventories are valued at the lower of cost or net realizable value ${ }^{22}$ consistent with U.S. GAAP. The valuation of inventory should be $\$ 10,320,800$ (net realizable value) as demonstrated in part 4 above. The loss on inventory write-down is recognized as an expense of the period. ${ }^{23}$

\footnotetext{
${ }^{1}$ http://www.nytimes.com/2005/12/25/weekinreview/25track.ready.html?ei=5070\&en=0b11f24f470ec $7 \mathrm{da} \& \mathrm{ex}=$ $1136610000 \&$ pagewanted $=$ print

${ }^{2}$ Heating, ventilation, and air conditioning.

${ }^{3}$ Financial Accounting Standards Board, Accounting Standards Codification, 835-20-15-5.

${ }^{4}$ ibid, 835-20-25-(1-5).

5 ibid, 450-05-3b.

${ }^{6}$ ibid, 450-20-25-2.

7 ibid, 450-30-20.

8 ibid, 450-30-50-1.

${ }^{9}$ ibid.

${ }^{10}$ ibid, 470-60-15-4.

11 ibid, 470-60-35-2.

12 ibid, 310-40-35-9.

13 ibid, 330-10-35-1.

${ }^{14}$ Ibid, 330-10-35-4.

${ }^{15}$ International Accounting Standard 23, Borrowing Costs, par. 6.

16 ibid, par. 25.

${ }^{17}$ Niswander, Frederick and Teresa Conover, International versus U.S. Accounting: What in the World is the Difference?, American Institute of Certified Public Accountants, 2008, pp. 6-3.

${ }^{18}$ ibid.

${ }^{19}$ ibid, Borrowing Cost, par. 14.

${ }^{20}$ ibid, pars. 31-34.

${ }^{21}$ International Accounting Standard 39, Financial Instruments: Recognition and Measurement, pars. 39-41.

22 International Accounting Standard 2, Inventories, pars. 9, 28.

${ }^{23}$ ibid, par. 34.
} 
NOTES 